\title{
Electronic Patient Records in an ultra-specialty hospital: An evaluation
}

\author{
Rajesh Kumar Sinha MS-MTDM \\ Associate Professor, Department of Health Information Management, Manipal College of Allied Health \\ Sciences, Manipal University, Manipal - 576 104, Karnataka, India \\ E-Mail address: rajesh.sinha@manipal.edu,raj_sin2001@rediffmail.com
}

Dola Saha MBA

Assistant Professor, Department of Health Information Management, Manipal College of Allied Health Sciences, Manipal University, Manipal - 576 104, Karnataka, India

E-Mail address: rajesh.sinha@manipal.edu, raj_sin2001@ rediffmail.com

\author{
Smriti Rawat M.Sc. HHIA \\ Department of Health Information Management, Manipal College of Allied Health Sciences, \\ Manipal University, Manipal - 576 104, Karnataka, India \\ E-Mail address: smriti24sweet@yahoo.com
}

Sri Lanka Journal of Bio-Medical informatics 2011:2(2):53-66

DOI: http://dx.doi.org/10.4038/sljbmi.v2i2.4158

\begin{abstract}
Objective: To compare an Electronic Patient Record (EPR) System in practice with Health Information Management System Society Electronic Health Record Definitional Model Version 1.0 (HIMSSv1) and assess the level of satisfaction among healthcare staff about the existing EPR system.

Method: The study was conducted in a super-specialty hospital in India. A checklist consisting of 30 features based on HIMSS standard was used to check the compliance of the present EPR in practice. A validated and pre-tested questionnaire, based on a five point Likert scale from 'strongly agree to strongly disagree', was used to measure the pre and post implementation EPR satisfaction among 62 healthcare professionals including doctors, nurses and administrative staff. A forum was also established to identify problems and give necessary recommendation to resolve issues involved in the acceptability of the present EPR in practice.
\end{abstract}

Result: It was observed that the EPR was only compliant with 12 features out of 30 in HIMSS. The employee satisfaction survey showed that $73 \%$ of doctors and nurses and $59 \%$ of administrative staff were dissatisfied with the pre-implementation assessment whereas $57 \%$ of doctors, $53 \%$ of nurses and $59 \%$ of administrative staff were dissatisfied with the customisation of the EPR in practice. A total of $40 \%$ of doctors, 53\% of nurses and $59 \%$ of administrative staff felt that the core incompetency with the present EPR was the present physical infrastructure. The post implementation survey result showed that $90 \%$ of doctors, $94 \%$ of nurses, and $88 \%$ of administrative staff were satisfied with the suggestions and changes to the existing EPR.

Conclusion: Understanding the factors that contribute to end user satisfaction and reinforcing them with trainings and awareness adds value and assists in continuous quality improvement, acceptability and sustainability of EPR.

Keywords - HIMSS; Electronic Patient Records; End user satisfaction; EPR

\section{Introduction}

Medical records are the principal repository of patient information. They consist of demographic data, health history, courses of treatment and recording of all events in the care of patients in a healthcare facility. In order to manage a large volume of patients without compromising on the quality of care provided to the patients, the hospitals have adopted a 
better and organised method to record patient health information by introducing EPR systems.

An EPR refers to an individual patient's medical record in digital format. EPR systems coordinate the storage and retrieval of individual patient record with the aid of computers. These systems are believed to increase physician efficiency and reduce costs, enhance multidisciplinary communication as well as promote standardisation of care ${ }^{(1)}$. However, while implementing, it should also be emphasised that the technology should complement and improve clinical care and not impose extra burdens on already overloaded medical staff.

In 2004, an estimate was made that one in seven hospitalisations occurred when medical records were not available. Additionally, One in five lab tests were repeated because results were not available at the point of care. EPRs are estimated to improve efficiency by $6 \%$ per year and the monthly cost of an EPR is offset by the cost of only a few unnecessary tests or $\operatorname{admissions}^{(2,3)}$.

The Healthcare Information and Management Systems Society (HIMSS) is the healthcare industry's membership organisation exclusively focused on providing global leadership for the optimal use of healthcare information technology (HIT) and management systems for the betterment of healthcare. The purpose of it is to develop a model for a fully functional EPR that includes an EPR definition, key attributes, essential requirements and evidence for each attribute that will demonstrate that the essential requirements have been met. The model that has been used for the assessment is HIMSS Electronic Health Record Definitional Model Version 1.0 (HIMSSv1) ${ }^{(4)}$.

This study was conducted with the objective of helping the hospital as well as the administration to identify the areas of improvisation on acceptability and sustainability of the EPR system. The implementation of recommendations brought cultural change to the organisation and it is a platform for future expansion of the EPR system in the hospital.

\section{Methods}

The present study was carried out in a super-specialty hospital of North India. The study was conducted in four phases:

Phase one consisted of the comparison of attributes and evidence of existing EPR System of the hospital with HIMSSv1 ${ }^{(4)}$. The standards of HIMSSv1 against which assessment was done were:

a.1.Security, reliability and real-time access to patient health record information

a.2.Capture and management of episodic and longitudinal Electronic Patient Record information

a.3.Electronic Patient Record system as a primary information resource during patient care

a.4.Electronic Patient Record system support for evidence based care to individual and groups of patients

a.5.Electronic Patient Record system support for continuous quality improvement, utilisation review, risk management, and performance monitoring

a.6.Electronic Patient Record system support for reimbursement 
a.7.Electronic Patient Record system support for clinical research, clinical trials, public health reporting, and population health initiatives

Based on the above seven standards, a checklist was developed where a total of 30 features were included for assessment. The checklist was used to assess the EPR where the related Compliance and Non-Compliance issues were noted.

Phase two consisted of the assessment of employee satisfaction about Electronic Patient Record (EPR) and establishment of a forum to discuss problems with the present EPR. To understand the satisfaction level of the end users, a structured interview was conducted with 62 randomly selected employees including 30 doctors, 15 nursing staff, and 17 Administrative staff using a validated pre-tested questionnaire. The first section of the questionnaire sought identification of the respondents. The satisfaction level was assessed by analysing responses to a set of 22 questions based on a five point Likert scale ie. strongly agree to strongly disagree. Inquiries were made regarding their satisfaction with the present EPR system in practice. Problems related to the present EPR were identified and recommendations were made accordingly.

Phase three consisted of identification of problems based on the satisfaction levels of survey results followed by discussions and implementation of recommendations.

Phase four consisted of measurement of the effectiveness of the implemented recommendations and identification of areas for further improvement. A post implementation satisfaction survey was conducted with the same respondents to identify the level of acceptance and satisfaction of the system. A validated and pretested questionnaire that included nine questions based on a five point Likert scale was used.

\section{Results and discussion}

The results are presented in the form of tables and discussion.

\section{Phase one. Assessment of the EPR system against HIMSSv1}

An observational study was conducted where each component of the existing EPR system of the hospital was compared with the standard criteria of HIMSSv1. (Table 1) using the checklist. The study results showed that the EPR system was compliant with Health Insurance Portability and Accountability Act, USA (HIPAA) requirements, the response time was appropriate with user's task and acceptance.

The system could be accessed by the users when required, but it was found to be noncompliant with HIMSSv1 for 99.99\% availability to the users (Table 1. Section 1.4). About $86 \%$ of the doctors, $74 \%$ of nurses, $70 \%$ of administrativ staff felt that the EPR system was not available to them always (Table 7. Section 7.8). The present EPR was found to be compliant with handling orders and doccumenting patient care and more than $75 \%$ of the care team members used the system for patient orders, care delivery, and monitoring patient outcomes (Table 1. Section 2.3). The satisfation results also showed that $80 \%$ of doctors, $80 \%$ of nurses, $82 \%$ of administrative staff agreed that the present EPR enhances the coordination of patient care (Table 7. Section 7.18). Non-compliance was seen in content standards of EPR such as DICOM and HL7. The system was compliant with standards in terms of integrating patient information (Table 1. Section 3.3). $77 \%$ of doctors, $73 \%$ of nurses 
and all the administrative staff claimed to agree with the same (Table 7. Section 7.7). But non-compliance was seen in many parameters such as; there is no organisational policy which states that the EPR is the source of patient information and also the law doesn't consider EPR to be a reliable source for official medical records. Therefore, paper records are still maintained. The EPR did not have any feature to identify medication errors nor did it have any impact on reducing the time required for nursing documentation. It did not support quality decision making in patient care. As the EPR did not endorse any content or documentation standards, it was found to be non compliant with documentation requirements. The EPR system was found to be compliant with the fact that more than $75 \%$ of the total employees cited that the EPR has been the reason for their job satisfaction (Table 1. Section 4.4) where the supporting reasons were user friendliness, data input, storage and retrieval, enhanced interdisciplinary communication, enhanced coordination of care, reduction of duplicate work, enhanced communication of patient information, and enhanced patient safety (Table 7).

The healthcare professionals and the administrators used to capture data by using the EPR system in quality and safety programmes to assess measure and manage quality (Table 1. Section 5.1). As the hospital is accredited by the National Accreditation Board for Hospital $(\mathrm{NABH})$, the NABH audits and other internal audits that are performed, depending on the EPR system to conduct reviews (Table1. Section 5.2).

The EPR has resulted in reduced errors in medical claims and the date of service with clinical information is available for billing purposes (Table 1. Section 6.1) Also, no extra tasks need to be performed on EPR which are exclusive for reimbursement (Table 1. Section 6.2). The cilinicians had to input additional data to support health management programmes and reporting in the hospital. The present EPR system does not supprt specific programmes to identify patients and track patients in health management (Table 1. Section 7.2).

The Organisation does not use EPR system in clinical research or for public health requirements (Table 1. Section 7.3). The EPR did not provide any information to clinicians and researchers for clinical trials (Table 1. Section 7.4). The above results show that the present EPR in the hospital was only compliant with 12 features of HIMSSv1 and that it was not compliant with 18 features. This may be because the EPR is not used for the purpose for which it was intended.

Table 1. Assessment of the EPR system against HIMSSv1

\begin{tabular}{|l|l|l|l|}
\hline SI. & $\begin{array}{l}\text { HIMSSv1 standard criteria } \\
\text { and parameters }\end{array}$ & C & NC \\
\hline 1 & \multicolumn{1}{|l|}{$\begin{array}{l}\text { Security, reliability and real-time access to patient health record } \\
\text { information }\end{array}$} & \multicolumn{2}{|l|}{} \\
\hline 1.1 & Satisfy HIPAA requirements & $\sqrt{ }$ & \multicolumn{1}{|l|}{} \\
\hline 1.2 & $99.99 \%$ available for access & - & - \\
\hline 1.3 & $\begin{array}{l}\text { Response time appropriate for } \\
\text { task completion and user } \\
\text { acceptance }\end{array}$ & $\sqrt{ }$ & - \\
\hline 1.4 & $\begin{array}{l}\text { Access where and when needed } \\
\text { for patient care }\end{array}$ & $\sqrt{ }$ & - \\
\hline
\end{tabular}




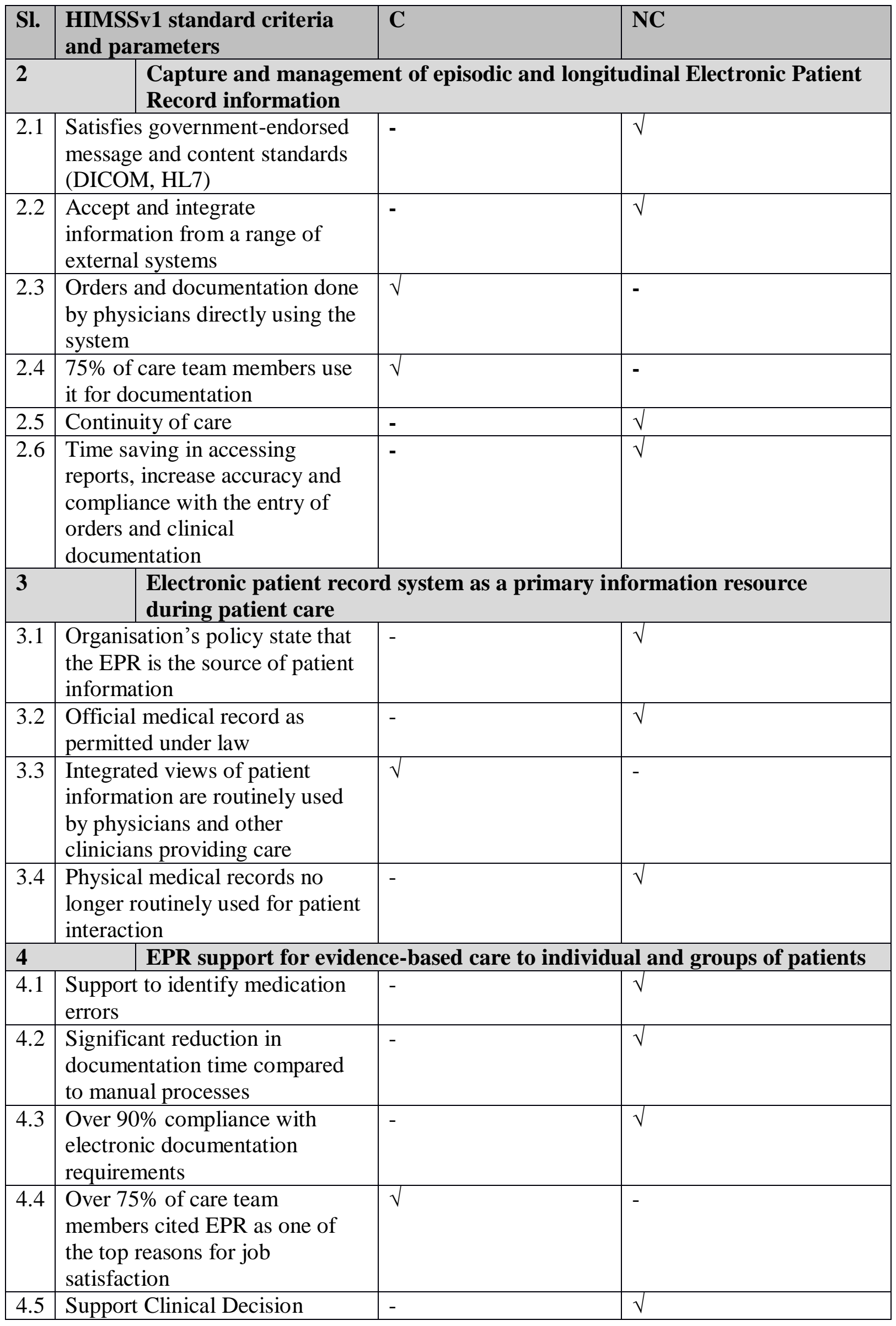




\begin{tabular}{|c|c|c|c|}
\hline SI. & $\begin{array}{l}\text { HIMSSv1 standard criteria } \\
\text { and parameters }\end{array}$ & $\mathrm{C}$ & NC \\
\hline & Support System & & \\
\hline 5 & \multicolumn{3}{|c|}{$\begin{array}{l}\text { EPR Support for continuous quality improvement, utilisation review, risk } \\
\text { management, and performance monitoring }\end{array}$} \\
\hline 5.1 & $\begin{array}{l}\text { Data captured in the EPR } \\
\text { system is the source used by the } \\
\text { organisation's quality and safety } \\
\text { programme to assess, measure, } \\
\text { and manage quality }\end{array}$ & $\sqrt{ }$ & - \\
\hline 5.2 & $\begin{array}{l}\text { The auditor relied on EPR } \\
\text { documentation to conduct } \\
\text { review rather than the use } \\
\text { physical medical records }\end{array}$ & $\sqrt{ }$ & - \\
\hline 5.3 & $\begin{array}{l}\text { The organisation has multiple } \\
\text { examples where the EPR system } \\
\text { helped in meeting regulatory, } \\
\text { safe practice, and quality } \\
\text { initiatives }\end{array}$ & - & $\sqrt{ }$ \\
\hline 5.4 & $\begin{array}{l}\text { Decreased incidences of } \\
\text { undetected signs and symptoms } \\
\text { of impending deterioration of } \\
\text { patients' conditions and } \\
\text { increased incidences of timely } \\
\text { intervention }\end{array}$ & - & $\sqrt{ }$ \\
\hline \multicolumn{2}{|r|}{\begin{tabular}{l|l} 
& Electronic Patient Reco
\end{tabular}} & d s & reimbursement \\
\hline 6.1 & $\begin{array}{l}\text { The clinically automated } \\
\text { revenue cycles - examples of } \\
\text { reduced error rates on claim }\end{array}$ & $\sqrt{ }$ & - \\
\hline 6.2 & $\begin{array}{l}\text { The clinical information needed } \\
\text { for billing is available on the } \\
\text { date of service }\end{array}$ & $\sqrt{ }$ & - \\
\hline 6.3 & $\begin{array}{l}\text { Physicians and clinical teams } \\
\text { perform extra tasks exclusively } \\
\text { for reimbursement }\end{array}$ & - & $\sqrt{ }$ \\
\hline 7 & \multicolumn{3}{|c|}{\begin{tabular}{l|l} 
Electronic Patient Record system support for clinical research, clinical \\
trials public health reporting, and populating health initiatives
\end{tabular}} \\
\hline 7.1 & $\begin{array}{l}\text { The organisation has a specific } \\
\text { programme when the EPR } \\
\text { system is used to identify and } \\
\text { track patients in health } \\
\text { management and/or disease } \\
\text { management programmes? }\end{array}$ & - & $\sqrt{ }$ \\
\hline 7.2 & $\begin{array}{l}\text { Clinicians perform additional } \\
\text { data entry to support health } \\
\text { management programmes and } \\
\text { reporting }\end{array}$ & $\sqrt{ }$ & - \\
\hline 7.3 & $\begin{array}{l}\text { Organisation has a history and } \\
\text { examples of using the EPR }\end{array}$ & - & $\sqrt{ }$ \\
\hline
\end{tabular}




\begin{tabular}{|l|l|l|l|}
\hline SI. & $\begin{array}{l}\text { HIMSSv1 standard criteria } \\
\text { and parameters }\end{array}$ & C & NC \\
\hline $\begin{array}{l}\text { system for clinical research and } \\
\text { responding to public health } \\
\text { requirements }\end{array}$ & $\begin{array}{l}\text { EPR system provide information } \\
\text { to the clinicians and researchers } \\
\text { for clinical trials }\end{array}$ & - & $\sqrt{ }$ \\
\hline
\end{tabular}

Note: $\mathrm{C}=$ Compliant, $\mathrm{NC}=$ Non-Compliant

\section{Phase two. Assessment of user satisfaction with the EPR system}

The result of the user satisfaction survey is presented in the following pages in the form of tables and discussion. Table 2 describes the respondents with respect to the designation they held in the hospital. Eight out of 30 doctors were consultants whereas 22 were senior consultants. Out of a total of 15 nurses, four were nurses in-charge and 11 were staff nurses. Among Administrative Staff one was in charge of the out patient department, two were counsellors and 14 were front office staff.

Table 2. Characteristics of the respondents

\begin{tabular}{|l|l|l|l|l|l|l|}
\hline \multicolumn{2}{|c|}{ Doctors= 30 } & \multicolumn{3}{c|}{ Nurses = 15 } & \multicolumn{1}{c|}{ Administrative Staff = 17 } \\
\hline $\begin{array}{l}\text { Senior } \\
\text { Consultant }\end{array}$ & Consultant & $\begin{array}{l}\text { In- } \\
\text { charge }\end{array}$ & $\begin{array}{l}\text { Staff } \\
\text { Nurse }\end{array}$ & $\begin{array}{l}\text { OPD } \\
\text { In-charge }\end{array}$ & Counselor & $\begin{array}{l}\text { Front } \\
\text { office staff }\end{array}$ \\
\hline 22 & 8 & 4 & 11 & 1 & 2 & 14 \\
\hline
\end{tabular}

Note: $\mathrm{n}=$ Total number of Respondents

Table 3 describes the respondents with respect to their experience in terms of the total number of years of work experience. 31 respondents had more than three years, 24 respondents had one to three years and seven respondents had less than one year of working experience.

Table 3. Distribution of respondents according to years of experience

\begin{tabular}{|l|l|l|l|}
\hline \multirow{2}{*}{ Employee Group } & \multicolumn{3}{|c|}{ Years of Experience } \\
\cline { 2 - 4 } & $<$ 1 year & 1 Year -3 Years & $>$ 3 Years \\
\hline Doctors $(n=30)$ & - & $6 \%(n=2)$ & $93 \%(n=28)$ \\
\hline Nurses $(n=15)$ & $20 \%(n=3)$ & $66 \%(n=10)$ & $13 \%(n=2)$ \\
\hline $\begin{array}{l}\text { Administrative } \\
\text { Staff }(n=17)\end{array}$ & $35.5 \%(n=4)$ & $70.5 \%(n=12)$ & $6 \%(n=1)$ \\
\hline
\end{tabular}

Note: $\mathrm{n}=$ Total number of Respondents

Table 4 describes the respondents according to the number of years they have worked in the present hospital. $13 \%$ of doctors, $33 \%$ of nurses and $23 \%$ of administrative staff had worked for less than six months. $23 \%$ of doctors, $26 \%$ of nurses and $41 \%$ of administrative staff were with the hospital for six months to a year and $63 \%$ of doctors, $40 \%$ of nurses and $35 \%$ of administrative staff were working in the particular hospital for more than a year. 
Table 4. Distribution of the respondents according to number of years they have worked in the present hospital

\begin{tabular}{|l|l|l|l|}
\hline \multirow{2}{*}{ Employee group } & \multicolumn{3}{|c|}{ Time period worked in the present hospital } \\
\cline { 2 - 4 } & \multicolumn{1}{|c|}{ 6 6 months } & \multicolumn{1}{c|}{ 6 months - 1 Year } & \multicolumn{1}{c|}{ Year } \\
\hline Doctors $(\mathrm{n}=30)$ & $13 \%(\mathrm{n}=4)$ & $23 \%(\mathrm{n}=7)$ & $63 \%(\mathrm{n}=19)$ \\
\hline Nurses $(\mathrm{n}=15)$ & $33 \%(\mathrm{n}=5)$ & $26 \%(\mathrm{n}=4)$ & $40 \%(\mathrm{n}=6)$ \\
\hline $\begin{array}{l}\text { Administrative } \\
\text { Staff }(\mathrm{n}=17)\end{array}$ & $23.5 \%(\mathrm{n}=4)$ & $41 \%(\mathrm{n}=7)$ & $35 \%(\mathrm{n}=6)$ \\
\hline
\end{tabular}

Note: $\mathrm{n}=$ Total number of Respondents

Table 5 describes the respondents on the basis of their knowledge of basic functionality of computers. All doctors, $94 \%$ of nurses and $100 \%$ of administrative staff said that they posses basic knowledge on computers. Only $6 \%$ of nurses said that they did not know the basic functionality of computers.

Table 5. Distribution of respondents according to knowledge on basic functionality of computers

\begin{tabular}{|l|l|l|}
\hline \multirow{2}{*}{ Employee Group } & \multicolumn{2}{|c|}{ Knowledge on basic functionality of computer } \\
\cline { 2 - 3 } & \multicolumn{1}{|c|}{ Yes \%(n) } & \multicolumn{1}{c|}{ No \%(n) } \\
\hline Doctors $(\mathrm{n}=30)$ & $100 \%(\mathrm{n}=30)$ & - \\
\hline Nurses $(\mathrm{n}=15)$ & $94 \%(\mathrm{n}=14)$ & $6 \%(\mathrm{n}=1)$ \\
\hline $\begin{array}{l}\text { Administrative Staff } \\
(\mathrm{n}=17)\end{array}$ & $100 \%(\mathrm{n}=17)$ & - \\
\hline
\end{tabular}

Note: $n=$ Total number of Respondents

Table 6 describes the respondents with respect to prior usage of EPRs. $13 \%$ of doctors, $26 \%$ of nurses and $5 \%$ of administrative staff had used EPRs before.

Table 6. Distribution of respondents on the basis of prior use of Electronic Patient Records

\begin{tabular}{|l|l|l|}
\hline \multirow{2}{*}{ Employee Group } & \multicolumn{2}{|c|}{ Used Electronic Patient Record Before } \\
\cline { 2 - 3 } & \multicolumn{1}{|c|}{ Yes \%(n) } & \multicolumn{1}{c|}{ No \%(n) } \\
\hline Doctors $(\mathrm{n}=30)$ & $13 \%(\mathrm{n}=4)$ & $86 \%(\mathrm{n}=26)$ \\
\hline Nurses $(\mathrm{n}=15)$ & $26 \%(\mathrm{n}=4)$ & $73 \%(\mathrm{n}=11)$ \\
\hline $\begin{array}{l}\text { Administrative Staff } \\
(\mathrm{n}=17)\end{array}$ & $5 \%(\mathrm{n}=1)$ & $94 \%(\mathrm{n}=16)$ \\
\hline
\end{tabular}

Note: $\mathrm{n}=$ Total number of Respondents

The questionnaire used to assess employee satisfaction for EPR contained a section in which the respondents could choose a feature in the EPR that needed improvement and is incompetent. The features listed were: physical infrastructure, vocabulary, technical standards, interoperability, customisation and complexity.

The users rated complexity and customisation as major deficiencies with the present EPR system where $40 \%$ of the doctors, $53 \%$ of the nurses and $59 \%$ of the administrative staff felt 
that the functionality of the system was very complex and that can be a reason for the low acceptability of the system in practice (Table 8 ).

Table 7. Assessment of acceptability regarding EPR among employees

\begin{tabular}{|c|c|c|c|c|}
\hline Sl. & Parameters & $\begin{array}{l}\text { Doctors } \\
\mathrm{n}=\mathbf{3 0}\end{array}$ & $\begin{array}{l}\text { Nurses } \\
n=15\end{array}$ & $\begin{array}{l}\text { Administrative Staff } \\
\mathrm{n}=17\end{array}$ \\
\hline 7.1 & User friendly & $80 \%(n=24)$ & $73 \%(n=11)$ & $76 \%(\mathrm{n}=13)$ \\
\hline 7.2 & Data input & $77 \%(n=23)$ & $93 \%(n=14)$ & $88 \%(\mathrm{n}=15)$ \\
\hline 7.3 & Data storage & $90 \%(n=27)$ & $80 \%(n=12)$ & $88 \%(\mathrm{n}=15)$ \\
\hline 7.4 & Data retrieval & $87 \%(n=26)$ & $93 \%(n=14)$ & $82 \%(n=14)$ \\
\hline 7.5 & $\begin{array}{l}\text { Reduced time for } \\
\text { per patient handling }\end{array}$ & $80 \%(n=24)$ & $73 \%(\mathrm{n}=11)$ & $88 \%(n=15)$ \\
\hline 7.6 & Interoperability & $83 \%(n=25)$ & $80 \%(n=12)$ & $82 \%(n=14)$ \\
\hline 7.7 & $\begin{array}{l}\text { Integration of health } \\
\text { information }\end{array}$ & $77 \%(n=23)$ & $73 \%(\mathrm{n}=11)$ & $100 \%(\mathrm{n}=17)$ \\
\hline 7.8 & Timely accessible & $87 \%(n=26)$ & $73 \%(n=11)$ & $70 \%(n=12)$ \\
\hline 7.9 & $\begin{array}{l}\text { Pre implementation } \\
\text { assessment }\end{array}$ & $27 \%(n=08)$ & $20 \%(n=3)$ & $35 \%(n=06)$ \\
\hline 7.10 & Customisation & $43 \%(n=13)$ & $40 \%(n=6)$ & $41 \%(n=07)$ \\
\hline 7.11 & $\begin{array}{l}\text { Post } \\
\text { implementation } \\
\text { training }\end{array}$ & $80 \%(n=24)$ & $80 \%(\mathrm{n}=12)$ & $76 \%(\mathrm{n}=13)$ \\
\hline 7.12 & Technical support & $70 \%(n=21)$ & $80 \%(n=12)$ & $88 \%(n=15)$ \\
\hline 7.13 & $\begin{array}{l}\text { Promptness of } \\
\text { problem solving }\end{array}$ & $90 \%(\mathrm{n}=27)$ & $93 \%(n=14)$ & $94 \%(\mathrm{n}=16)$ \\
\hline 7.14 & Help desks & $77 \%(n=23)$ & $73 \%(n=11)$ & $82 \%(n=14)$ \\
\hline 7.15 & $\begin{array}{l}\text { Overall usability of } \\
\text { EPR system }\end{array}$ & $80 \%(n=24)$ & $93 \%(n=14)$ & $88 \%(n=15)$ \\
\hline 7.16 & Job satisfaction & $84 \%(n=25)$ & $80 \%(n=12)$ & $94 \%(n=16)$ \\
\hline 7.17 & $\begin{array}{l}\text { Interdisciplinary } \\
\text { communication }\end{array}$ & $87 \%(n=26)$ & $80 \%(n=12)$ & $88 \%(\mathrm{n}=15)$ \\
\hline 7.18 & $\begin{array}{l}\text { Enhanced } \\
\text { coordination of care }\end{array}$ & $80 \%(n=24)$ & $80 \%(n=12)$ & $82 \%(n=14)$ \\
\hline 7.19 & $\begin{array}{l}\text { Reduction of } \\
\text { duplicate work }\end{array}$ & $80 \%(n=24)$ & $100 \%(n=15)$ & $100 \%(\mathrm{n}=17)$ \\
\hline 7.20 & $\begin{array}{l}\text { Enhanced } \\
\text { communication }\end{array}$ & $77 \%(n=23)$ & $80 \%(n=12)$ & $88 \%(\mathrm{n}=15)$ \\
\hline 7.21 & $\begin{array}{l}\text { Enhanced patient } \\
\text { safety }\end{array}$ & $83 \%(n=25)$ & $80 \%(n=12)$ & $82 \%(n=14)$ \\
\hline 7.22 & Overall satisfaction & $83 \%(n=25)$ & $86 \%(n=13)$ & $88 \%(n=15)$ \\
\hline
\end{tabular}

Note: $\mathrm{n}=$ Total number of Respondents 
Table 8. Core area of incompetency with the EPR system identified by respondents

\begin{tabular}{|l|l|l|l|}
\hline Parameters & Doctors & Nurses & $\begin{array}{l}\text { Administrative Staff } \\
\mathbf{n}=\mathbf{1 7}\end{array}$ \\
\hline $\begin{array}{l}\text { Physical } \\
\text { Infrastructure }\end{array}$ & $13 \%(\mathrm{n}=04)$ & $7 \%(\mathrm{n}=01)$ & $12 \%(\mathrm{n}=02)$ \\
\hline Vocabulary & $17 \%(\mathrm{n}=05)$ & $13 \%(\mathrm{n}=02)$ & $6 \%(\mathrm{n}=01)$ \\
\hline $\begin{array}{l}\text { Technical } \\
\text { Standards }\end{array}$ & $7 \%(\mathrm{n}=02)$ & $7 \%(\mathrm{n}=01)$ & $0 \%$ \\
\hline Interoperability & $13 \%(\mathrm{n}=04)$ & $0 \%$ & $0 \%$ \\
\hline Customisation & $10 \%(\mathrm{n}=03)$ & $20 \%(\mathrm{n}=03)$ & $23 \%(\mathrm{n}=04)$ \\
\hline Complexity & $40 \%(\mathrm{n}=12)$ & $53 \%(\mathrm{n}=08)$ & $59 \%(\mathrm{n}=10)$ \\
\hline
\end{tabular}

Note: $\mathrm{n}=$ Total number of respondents

Pearsons Chi Square test was performed to verify association of employee satisfaction with the time period of experience. The test result score was found to be significant as Pearson Chi Square score was 44.023 with $\mathrm{p}<0.001$.

Pearsons Chi Square test was also performed to verify association of employee satisfaction with the working span in the hospital. The test result score was found to be significant as the score of Pearson Chi Square test was 6.170 with $p<0.05$.

\section{Phase 3. Solutions}

This phase of the study was focused to provide recommendations for the key areas of dissatisfaction identified in employee satisfaction survey regarding acceptability of EPR. The suggestions after analysis of the problems identified with respect to EPR were as follows:

1. Clinical Decision Support System will enhance patient safety by reminding the doctors in case of adverse drug interactions. Hence, Pop ups or reminders can be incorporated in the existing system to rule out medication error, adverse drug interactions and there by improve patient safety

2. Customisation of the layout is needed for different specialty as terminologies change

3. A Beginners Module should be designed for new staff

4. Training through the module should be completed before their deployment in respective departments

5. Assessment of the new staff based on the module to be designed which will evaluate staff for completeness, accuracy and timeliness 
6. For the old staff, refresher module (every six months) should be designed for reinforced training and assessment

\section{The rationale behind the above recommendations}

During the initial survey of employee groups it was evident that the commonest reason that had led to employee dissatisfaction was complexity of the EPR system (Table 8). Hence, it was initially proposed to change the layout and customise the format of EPR according to the departments and specialty, but it was not possible as any change in the format / layout of the EPR would incur a fee as the EPR was bought from a vendor outside India and as such an extra expense was not foreseen in the annual budget. The best possible solution in this situation was reinforced training throughout the organisation for the different groups of employees. The satisfaction survey indicated that the employees had a lot of problems and suggestions that were overlooked and ignored. Hence it was proposed that there was a need for a common platform to bring forth the issues that the employees had. The root cause analysis for employee dissatisfaction showed that new staff faced many problems in the initial stages. Hence it was proposed that in the process of recruitment one round of "computer proficiency testing" had to be included to assess computer aptitude of applicants. Employee induction classes "Know EPR" programme was proposed, for better employee acceptance.

\section{Implementation of recommendations:}

During the recruitment of new staff, 'computer proficiency test' has been included along with the regular interviews, so as to select staff who are computer literate. The test was so designed to elicit accuracy and speed as well as learning skills. Special induction classes were implemented for new staff to improve acceptance and efficiency. The classes were group specific ie. separate classes were held for doctors, nurses and administrative staff. This segregation was done to make teaching action specific. Refresher trainings were started for old staff, to teach any changes to layout and formatting. A 15 minute test was done to test accuracy, promptness and knowledge of options available. Data Entry Operators were recruited to reduce the workload of the clinical staff to document the discharge summaries and order entries.

A functional advisory team was formed with the following membership: Deputy Medical Superintendent, Quality Assurance Executive, Medical Coordinator, Nursing Superintendent, Senior Consultants and Residents of all departments. The team was to meet once a month to discuss issues pertaining to the EPR system. This meeting focused on incorporating changes in the format and vocabulary used in the EPR and also pharmacy updates. Any problem faced by the staff was highlighted and solved within 48 hours.

Reinforced training through Continuous Nursing Education (CNE) and Continuous Medical Education (CME) was also implemented where common problems are discussed in the presence of the Information Technology (IT) staff. This was conducted once a month. Morning meetings, departmental meetings and other functional committee meetings were initiated to form a platform to address IT related issues and problems. 


\section{Phase 4. Measurement of the effectiveness of the implemented recommendations and identification of areas for further improvement}

The objective of this phase was to measure the effectiveness of the implemented recommendations. The same respondents, ie. doctors, nurses and administrative staff were interviewed using a structured personal interview method. The results of the post implementation satisfaction survey to study the effectiveness of the recommendations is presented in the form of a table (Table 9) and discussion below.

Table 9. Results of the post-implementation satisfaction survey

\begin{tabular}{|c|c|c|c|c|}
\hline SI. & Parameters & $\begin{array}{l}\text { Doctors } \\
\mathrm{n}=\mathbf{3 0}\end{array}$ & $\begin{array}{l}\text { Nurses } \\
\mathrm{n}=15\end{array}$ & $\begin{array}{l}\text { Administrative Staff } \\
\mathrm{n}=\mathbf{1 7}\end{array}$ \\
\hline 9.1 & $\begin{array}{l}\text { Effectiveness of } \\
\text { the training }\end{array}$ & $74 \%(n=22)$ & $93 \%(n=14)$ & $70 \%(\mathrm{n}=12)$ \\
\hline 9.2 & Content of training & $74 \%(n=22)$ & $80 \%(\mathrm{n}=12)$ & $64 \%(n=11)$ \\
\hline 9.3 & $\begin{array}{l}\text { Decrease burden } \\
\text { of work due to } \\
\text { Data entry } \\
\text { operators }\end{array}$ & $83 \%(n=25)$ & $80 \%(n=12)$ & $88 \%(n=15)$ \\
\hline 9.4 & $\begin{array}{l}\text { Problems } \\
\text { addressed by } \\
\text { advisory team }\end{array}$ & $83 \%(n=25)$ & $73 \%(\mathrm{n}=11)$ & $94 \%(\mathrm{n}=16)$ \\
\hline 9.5 & $\begin{array}{l}\text { Cultural change to } \\
\text { improve EPR } \\
\text { acceptance }\end{array}$ & $87 \%(n=26)$ & $93 \%(n=14)$ & $88 \%(\mathrm{n}=15)$ \\
\hline 9.6 & $\begin{array}{l}\text { Usefulness of } \\
\text { refresher training }\end{array}$ & $83 \%(n=25)$ & $87 \%(n=13)$ & $88 \%(n=15)$ \\
\hline 9.7 & $\begin{array}{l}\text { CNE and CME as } \\
\text { a platform to raise } \\
\text { individual issues }\end{array}$ & $100 \%(n=30)$ & $93 \%(n=14)$ & 0 \\
\hline 9.8 & $\begin{array}{l}\text { Promptness of } \\
\text { solving / } \\
\text { addressing, all } \\
\text { issues raised in } \\
\text { different platforms }\end{array}$ & $87 \%(\mathrm{n}=26)$ & $100 \%(\mathrm{n}=15)$ & $94 \%(n=16)$ \\
\hline 9.9 & $\begin{array}{l}\text { Overall } \\
\text { effectiveness of } \\
\text { organisation -wide } \\
\text { initiatives for } \\
\text { improving } \\
\text { acceptability of } \\
\text { EPR }\end{array}$ & $90 \%(\mathrm{n}=27)$ & $94 \%(n=14)$ & $88 \%(\mathrm{n}=15)$ \\
\hline
\end{tabular}

Note: $n=$ Total number of respondents

The results of this survey showed that $74 \%$ of doctors, $93 \%$ nurses, and $70 \%$ of administrative staff felt that the trainings were useful and productive (Table 9. Section 9.1). Whereas $74 \%$ of doctors found the content of training to be functional, $80 \%$ nurses and $64 \%$ 
of administrative staff felt the content of training to be practical and applicable (Table 9. Section 9.2). $83 \%$ of doctors and $80 \%$ of nurses felt that their work on EPR had decreased due to the deployment of data entry operators. $88 \%$ of administrative staff felt that their typing work in the EPR decreased due to recruitment and staffing data entry operators (Table 9. Section 9.3). Threfore, it is evident that $84 \%$ of doctors, $73 \%$ of nurses and $94 \%$ of administrative staff felt that problems addressed in the advisory team meeting were solved (Table 9. Section 9.4).

A total of $87 \%$ of doctors, $93 \%$ of nurses and $88 \%$ of administrative staff rated the cultural changes to improve the EPR acceptance as satisfactory (Table 9. Section 9.5). 84\% of doctors, $87 \%$ of nurses and $88 \%$ of administrative staff found the refresher training useful and practical. The problem related to the timings of training were solved with the peer departmental training where the employees attending training sessions needed some relaxation or some appraisals that would encourage all employees to participate (Table 9. Section 9.6). Continuing Nursing Education and Continuting Medical Educatin programmes were used as a platform to discuss EPR related problems, as a result all the doctors and $93 \%$ of nurses agreed to the idea and rated it as satisfactory, (Table 9. Section 9.7) and $87 \%$ of doctors, all the nurse and $94 \%$ of administrative staff felt that the issues raised in the forums and platforms established were solved promptly ( Table 9. Section 9.8).

The overall satisfaction rating of the organisation wide initiatives taken after the recommendations were found to be satisfactory where $90 \%$ of doctors, $94 \%$ of nurses, $88 \%$ administrative staff ( Table 9. Section 9.9). Reinforced training sessions for the old staff and "Know EPR" for new doctors made EPR system more acceptable and clarified many confusions regarding its functioning, discharge summary options and language. Advisory Team Meeting and CME and a follow up was done by the staff with positive results.

Attrition rate was high in the administration staff, therefore special classes were held for this target group. Policy for recruitment had been recommended for this particualr group as this is the first point of contact for patients with the hospital and any delay or mistake in data entry would lead to patient disatisfaction. Overall employees felt satisfied as they had access to a platform where their problems can be heard and solved. As the training sessions were group specific, acceptance was good. If at the ground level some problems went unnoticed, advisory team meetings were helped to identify such problems and initiate action. Hence, all the above mentioned factors contributed to elevate the satisfaction level of employees.

\section{Conclusion}

The result of the study suggest that the best way to raise the level of acceptance of an IT Application such as an Electronic Patient Record System among its users highly depend on thorough training, assessment and feedback. This helps the employees to gain knowledge about the system and establish a culture of continuous quality improvement. The study also suggests that the training sessions should be specific. The content of the trainings should be appropriate and continuous progression in the content is also necessary. Hospitals should have well established forums and committees to address employee's operational and functional issues related to EPR. The follow up of the discussion in these committees should be regular and prompt so that employees maintain confidence in them. 


\section{References}

1. The Best Medical Care in the U.S. How Veterans Affairs transformed itself - and what it means for the rest of us. BusinessWeek, Red Oak, IA (USA). 17, 2006.

2. Smaltz, Detlev and Eta Berner. The Executive's Guide to Electronic Patient Records. Health Administration; 2007.p.03.

3. Evans DC, Nichol WP, Perlin JB. "Effect of the implementation of an enterprise-wide Electronic Patient Record on productivity in the Veterans Health Administration". Health Econ Policy Law 2006;1(Pt 2):163-9. Also available from http://journals.cambridge.org/action/displayAbstract;jsessionid=7C274D08947B0625B3 B540BEF2E70367.tomcat 1 ?fromPage=online\&aid=416400.http://dx.doi.org/10.1017/S1 744133105001210

4. HIMSS Electronic Health Record: Definitional Model Version 1.0. Available from URL; http://www.himss.org/content/files/EHRAttributes.pdf 